\title{
Estimation of total volatile fatty acid (VFA) from total organic carbons (TOCs) assessment through in vitro fermentation of livestock feeds
}

\author{
Md. Mukhlesur Rahman ${ }^{1,2 \star}$, Mohamad Amran Mohd. Salleh ${ }^{1}$, Nasrin Sultana ${ }^{3}$, M. J. Kim ${ }^{4}$ and \\ Chang Six Ra ${ }^{4 *}$ \\ ${ }^{1}$ Institute of Advanced Technology, University Putra Malaysia, UPM 43400, Serdang, Selangor, Malaysia. \\ ${ }^{2}$ Department of Animal Science, Bangladesh Agricultural University, Mymensingh-2202, Bangladesh. \\ ${ }^{3}$ Department of Animal Science, University Putra Malaysia, UPM 43400, Serdang, Selangor, Malaysia. \\ ${ }^{4}$ Department of Animal Life System, Kangwon National University, Chuncheon 200-701, South Korea.
}

Accepted 7 February, 2013

\begin{abstract}
In vitro fermentation of 32 available feedstuffs was performed to investigate the relationship between soluble total organic carbon (TOCs) and volatile fatty acids (VFA) production. Correlation between VFA and methane $\left(\mathrm{CH}_{4}\right)$ emission was also investigated. For this purpose, a fermentation reactor was designed to collect liquor for estimating TOCs and VFA during in vitro fermentation. The results showed that the VFA production was proportional to TOCs produced during in vitro fermentation $(y=$ $\left.1.1169 \mathrm{x}, r^{2}=0.86\right)$. Forages produced more acetate $(A)$ than propionate $(P)$ and the $A: P$ ratio of energy, protein and forages were 1.77:1, 2.08:1 and 2.80:1, respectively. $\mathrm{CH}_{4}$ production of feeds was also found proportional to VFA produced during in vitro fermentation $\left(y=0.0508 x, r^{2}=0.58\right)$. It might be stated from this in vitro study that TOCs production could be used as an indirect index for estimation of VFA of livestock feeds.
\end{abstract}

Key words: Livestock feed, in vitro fermentation, total organic carbons, volatile fatty acids.

\section{INTRODUCTION}

The ruminant animal depends on microorganisms to digest roughages (cell wall polysaccharides) and other feedstuffs to produce energy sources, such as volatile fatty acids (VFA) and other organic acids. VFA are the chief energy source of ruminant animals. Usually, acetate, propionate and butyrate account for more than $95 \%$ of the VFA found in rumen fluid (Bannink et al., 2006). Numerous microorganisms from different species (bacteria, archaea, protozoa and fungi) are involved in the ruminal digestion process to digest the fibrous constituents and other feed materials. VFA are produced

*Corresponding author. E-mail: mmrahmanz@gmail.com, changsix@kangwon.ac.kr. in large amounts through ruminal fermentation and are of paramount importance in that they provide greater than $70 \%$ of the ruminant's energy supply. Virtually all of the acetic, propionic and butyric acids are produced in a complex microbial metabolism in the rumen and are absorbed across the ruminal epithelium. The absorbed VFAs are transported through ruminal veins to the portal vein and finally reach to the liver.

In vitro fermentation through mixed ruminal inoculums is a good way of identification of VFA of different feedstuffs. Fermentation of fibrous materials or cellulose fraction is likely to produce a higher molar proportion of acetate and a lower proportion of propionate. On the other hand, feed with low fiber content would be expected to result in a reduction in the $A: P$ ratio during rumen fermentation (Dougherty, 1984; Orskov and Ryle, 1990). 
Carbohydrate is the chief source of acetate and butyrate in the ruminal fermentation. The synthesis of acetate and butyrate in the rumen results in an increase hydrogen $\left(\mathrm{H}_{2}\right)$ and the methanogens in the rumen produces $\mathrm{CH}_{4}$ by utilizing $\mathrm{H}_{2}$ and $\mathrm{CO}_{2}$ (Widiawati and Thalib, 2007) during in vitro fermentation. The primary end products of fermentation in the rumen are VFA. Concentrations and molar proportions of VFA in the rumen are commonly measured based upon the assumption that relative concentrations represent either VFA production, absorption or both. Differences in VFA profiles have been reported between in vitro fermentation and the rumen itself, suggesting possible differences either in VFA absorption by the host animal, or in microbial populations responsible for VFA production (Weimer et al., 2011). According to Embden-Meyerhof-Parnas pathway, the stoechiometry of the anaerobic fermentation can be stated as

\section{(i) $2 \mathrm{H}$ producing reactions:}

$$
\begin{aligned}
& \text { Glucose } \rightarrow 2 \text { pyruvate }+4 \mathrm{H} \\
& \text { Pyruvate }+\mathrm{H}_{2} \mathrm{O} \rightarrow \text { acetate }+\mathrm{CO}_{2}+2 \mathrm{H}
\end{aligned}
$$

(ii) $2 \mathrm{H}$ using reactions:

$$
\begin{aligned}
& \text { Pyruvate }+4 \mathrm{H} \rightarrow \text { propionate }+\mathrm{H}_{2} \mathrm{O} \\
& \text { Pyruvate }+4 \mathrm{H} \rightarrow \text { butyrate }+2 \mathrm{H}_{2} \mathrm{O}
\end{aligned}
$$

VFA are involved in important metabolic and productive activities in ruminant animals. Acetic acid is utilized minimally in the liver, and is oxidized throughout most of the body to generate ATP. Another important use of acetate is as the major source of acetyl CoA for synthesis of lipids. Propionic acid is almost completely removed from portal blood by the liver. Within the liver, proprionate serves as a major substrate for gluconeogenesis, which is absolutely critical to the ruminant because almost no glucose reaches the small intestine for absorption. Butyric acid, most of which comes out of the rumen as the ketone beta-hydroxybutyric acid, is oxidized in many tissues for energy production. Essentially, all the glucose in the lactose was synthesized in the liver and most of the synthesis was from proprionic acid generated by fermentation. Likewise, much of the fat is synthesized from ruminal acetate. So, many processes that are supported by volatile fatty acids, comes from a complex reaction of microbial enzymes on feedstuffs.

Important amylolytic bacteria like Prevotella ruminicola and Butyrivibrio fibrisolvens synthesize acetate and butyrate and consequently form $\mathrm{H}_{2}$ and $\mathrm{CO}_{2}$ (Rossi et al., 2001). Rossi et al. (2001) also stated that $6 \%$ gross energy was lost as $\mathrm{CH}_{4}$, particularly in high forage diets characterized by a high number of cellulolytic bacteria in the rumen. Microbial fermentation of forages produced VFA, $\mathrm{H}_{2}$ and $\mathrm{CO}_{2}$, and subsequently $\mathrm{CH}_{4}$ during methanogenesis. Rapidly fermentable carbohydrates yield relatively higher propionate as compared to acetate, and the reverse takes place when slowly fermentable carbohydrates are fermented (Getachew et al., 1998). Analysis and estimation of VFA of fermented feed is very expensive. So, it is necessary to develop an alternate way of estimating VFA in a cheaper way. Total organic carbon (TOC) is produced after initial breakdown of feeds and it might be an indirect index of VFA estimation. There is a complex biochemical and metabolic changes among TOC, VFA and $\mathrm{CH}_{4}$ after digestion of feedstuffs in the rumen. Therefore, the present study was carried out to identify the TOC and VFA production characteristics of feedstuffs and also to establish the correlation between TOC and VFA production during in vitro fermentation of livestock feeds.

\section{MATERIALS AND METHODS}

\section{Apparatus for in vitro fermentation}

Two types of fermentation reactors were designed to evaluate feedstuffs through in vitro test, and also to analyze the VFA and TOCs production during fermentation. One reactor was used to capture the gas only and another type was arranged with $50 \mathrm{ml}$ syringe and tube to collect liquor samples during the fermentation. The fermentation was performed in a shaking incubator (VS- 8480 $\mathrm{SR}$ ) for $48 \mathrm{~h}$.

\section{Preparation for in vitro fermentation}

In vitro fermentation of the 32 available feed ingredients (13 energyrich and 10 protein-rich feeds and 9 roughages) was performed to assess VFA production characteristics of feeds (Table 1). All samples were arranged in triplicates. Clean, dry, nylon bags (mesh size: 30 to $50 \mu \mathrm{m}$; dimension: $5 \times 10 \mathrm{~cm}$ ) were rinsed in acetone for 3 to $4 \mathrm{~min}$ and completely air-dried before sampling. After measuring the weight of the nylon bag, $1.6 \mathrm{~g}$ of basal feeds was added as the correction factor and for optimizing the best ecosystem conditions for microbial growth. The basal feed was composed of $0.8 \mathrm{~g}$ ground rice straw and $0.8 \mathrm{~g}$ formula feed. Then, $2.4 \mathrm{~g}$ of ground experimental feeds were put into each bag. The nylon bags were sealed after 3 beads and each bag were added to ensure complete immersion in the buffer solution. The spherical beads were composed of metallic alloy with $6 \mathrm{~mm}$ diameter and 1.6 $\mathrm{g}$ weight. Prepared nylon bags with feed samples were placed in the marked fermentation reactor for fermentation.

Buffer solution was prepared according to the method described by Menke and Steingass (1988), and the $\mathrm{pH}$ was adjusted to 6.8 . Four hundred (400) $\mathrm{ml}$ buffer solution was added to each fermentation reactor and warmed up to $37^{\circ} \mathrm{C}$ for $30 \mathrm{~min}$. Then, 80 $\mathrm{ml}$ diluted rumen inoculum was added to each reactor as a source of microorganisms. Rumen fluid and contents were collected from fistulated Korean cattle (maintained at National Institute of Animal Science on a standard diet: concentrate : roughage $=40: 60$ ) at approximately $30 \mathrm{~min}$ after feeding, and put it into a pre-warmed insulated container. The filtration occurred in an anaerobic condition through cheese cloth. Anaerobic conditions were maintained by injecting $\mathrm{CO}_{2}$ gas, and the liquor was homogenized by blending at high speed for $30 \mathrm{~s}$. Then, fresh rumen fluid was diluted at a ratio of 1:2 with the buffer solution. The reactors were then incubated at $39^{\circ} \mathrm{C}$ and agitated at $170 \mathrm{rpm}$ for $48 \mathrm{~h}$ for further utilization. In vitro fermentation of the feeds was fermented in vitro according to the 
Table 1. TOC and VFA production traits of available livestock feeds during in vitro fermentation.

\begin{tabular}{llll}
\hline Feed type & Energy feed & Protein feed & Forages \\
\hline & Corn & Corn gluten meal & Alfalfa \\
& Corn cob & Brewers grain & Oat \\
& Corn gluten feed & Cottonseed meal & Rye grass \\
& Corn distillers grain & Soybean meal & Perennial grass \\
& Wheat & Soybean oil cake & Orchard grass \\
& Wheat bran & Rape seed meal & Timothy grass \\
& Rice bran & Coconut meal & Talfescue grass \\
& Beet pulp & Lupine & Crain grass \\
& Rye & Corn cake & Rice straw \\
& Tapioca & Palm cake & \\
& Cottonseed hull & & \\
& Lupine hull & & \\
Average TOC production (g/kg digested feed) & Soybean hull & & 119.63 \\
Acetate : propionate $(A: P)$ & 171.36 & 157.28 & $2.80: 1$ \\
\hline
\end{tabular}

principles of Tilley and Terry (1963).

\section{Sampling and analysis}

Liquor samples were collected using the installed syringe at 0,12 , 24 and $48 \mathrm{~h}$ to analyze the TOC levels and total VFA production. VFA production was analyzed using the method described by Gatachew et al. (2005). Approximately $6 \mathrm{ml}$ of the liquid contents were transferred into $10-\mathrm{ml}$ plastic tubes and centrifuged at 11,000 rpm for $10 \mathrm{~min}$. Subsequently, $3 \mathrm{ml}$ of the supernatant was removed and centrifuged again under the same conditions. Thereafter, a 0.1$\mathrm{ml}$ aliquot of supernatant was pipetted into an auto-sampler vial containing $0.9 \mathrm{ml}$ of internal standard $(0.75 \mathrm{mM} 3$-methylvaleric acid). VFA levels were analyzed using capillary gas chromatography (GC, Hewlett Packard 5890). TOC production was analyzed by a total organic carbon analyzer (Shimadzu, TOC5000A). TOC was measured from the cultured supernatants, after centrifuging the samples at $11,000 \mathrm{rpm}$ for $10 \mathrm{~min}$. The volume of the collected gases was measured using a gas flow meter (GAST, DOA-P704-AC), and $\mathrm{CH}_{4}$ was analyzed by injecting $60 \mathrm{ml}$ of gas into a GC (Varian, 450-GC) equipped with a thermal conductivity detector. All feed analyses were done according to standard methods (AOAC, 2005).

\section{Statistical analysis}

Data were analyzed using the Microsoft Office Excel (2007) program. Correlation between the parameters was studied with Sigma Plot analysis (8.0).

\section{RESULTS AND DISCUSSION}

\section{VFA and TOCs production}

The graphical presentation of VFA (acetate, propionate and butyrate) produced from different feed ingredients is shown in Figure 1. Comparatively higher propionate was produced from energy (33.88\%) and protein (29.28\%) feeds than forages (22.63\%). On the contrary, acetate production was comparatively higher in forages $(63.16 \%)$ than energy $(60.19 \%)$ and protein rich $(60.79 \%)$ feeds. Higher acetate : propionate ratio (2.8:1) was found in forages as compared to energy (1.77:1) and protein feeds (2.08:1) which might be due to presence of structural carbohydrates (cellulose and hemi-cellulose) in forages (Table 1). Butyric acid production was 5.87, 9.92 and $14.21 \%$ in the case of energy, protein and forage feeds, respectively. Forages contain more acid detergent fiber (ADF) and neutral detergent fiber (NDF) that helps to increase $A$ : $P$ ratio during anaerobic fermentation, and the molar proportion of different fatty acid production depends on the structural composition of the feed ingredients (Getachew et al., 1998). Readily degradable carbohydrates produced relatively higher propionate as compared to acetate, and cell wall containing fibrous carbohydrate (cellulose) produced more acetate than propionate. Relatively higher acetate production from forages and higher propionate from energy and protein rich feeds in this experiment also support the study of Widiawati and Thalib (2007) and Keir et al. (1997). Dijkstra et al. (2005) also stated that starch and sugars are generally fermented more rapidly, and yield more propionate and butyrate as compared to acetate. Higher average TOC production was found in energy feed $(171.36 \mathrm{~g} / \mathrm{kg}$ digested feed) as compared to protein (157.28 $\mathrm{g} / \mathrm{kg}$ digested feed) and forage $(119.63 \mathrm{~g} / \mathrm{kg}$ digested feed) feeds during $24 \mathrm{~h}$ of in vitro fermentation.

Figure 2 shows the regression correlation between produced TOCs and total VFA during in vitro fermentation. It was found that comparatively lower TOCs producing feeds produced lower VFA and higher TOCs producing feeds produced higher VFA. Total VFA was proportional to the produced TOCs $\left(y=1.1169 x, r^{2}=\right.$ $0.86)$, and hence, total VFA could be estimated from the 


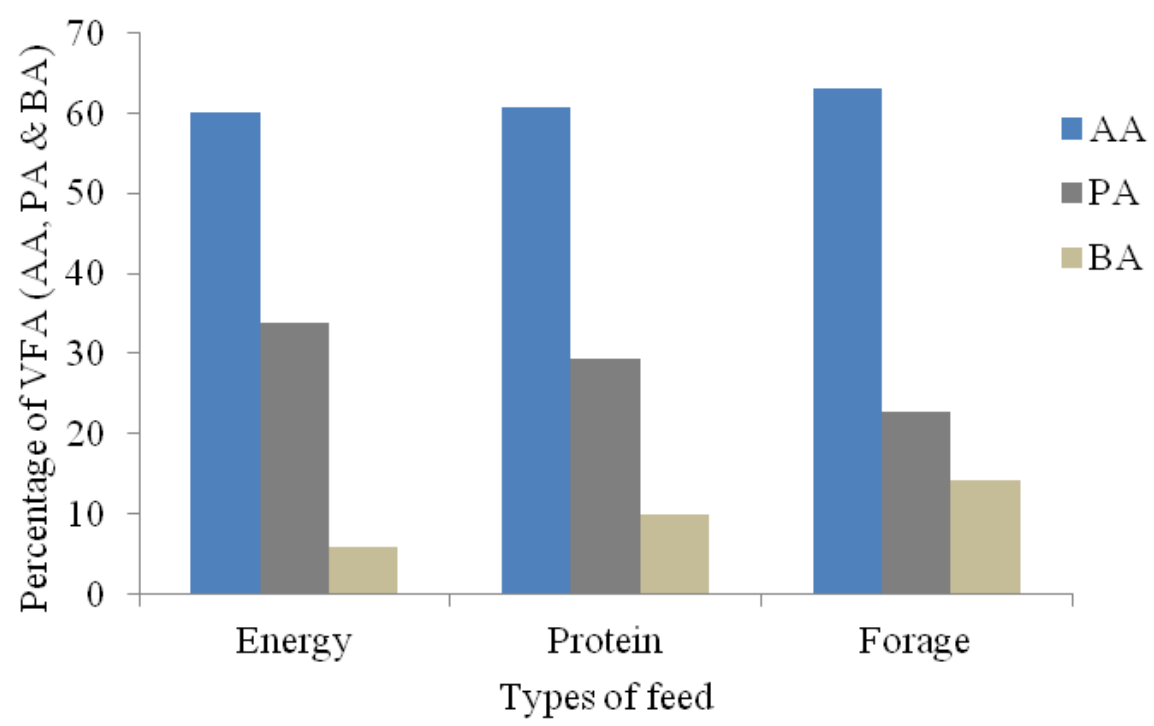

Figure 1. Status of VFA produced during in vitro fermentation.

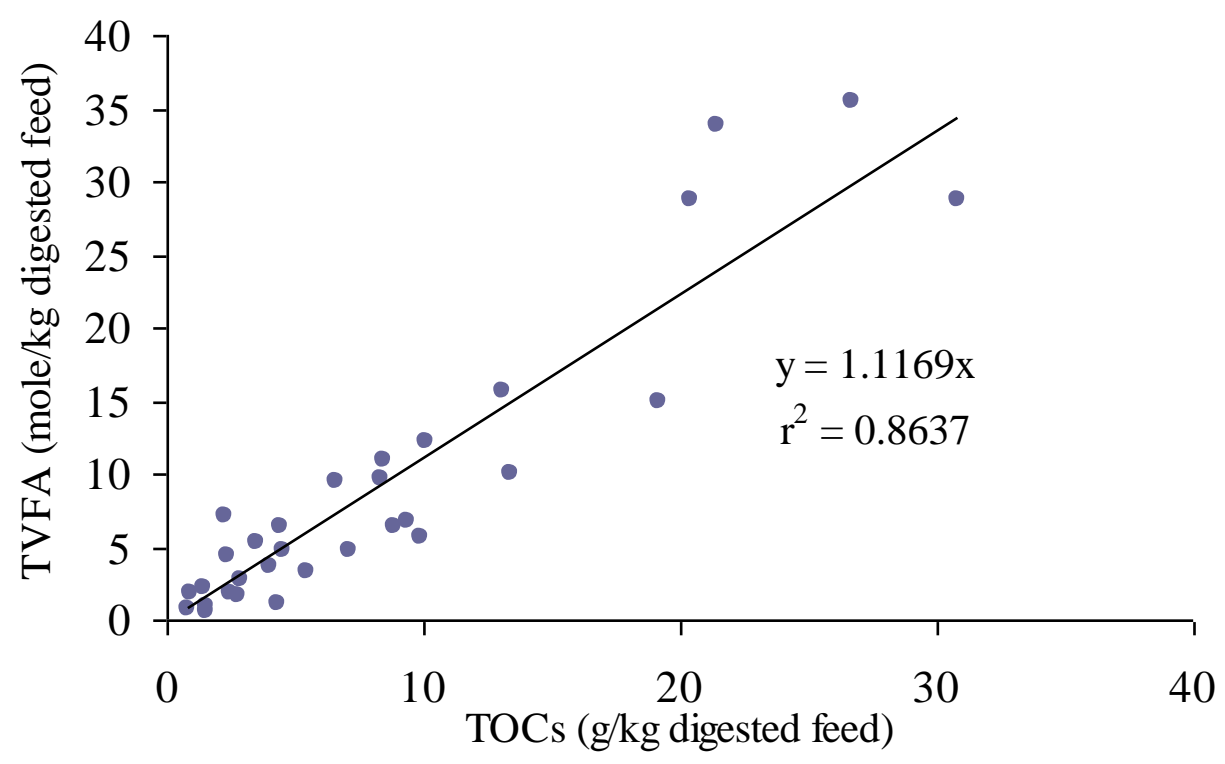

Figure 2. Correlation between TOCs and total VFA production.

produced TOCs during in vitro fermentation. It might be stated that TOCs could be used as an indirect index or tool for VFA estimation. It would be an effective alternative technology of estimating VFA in a cheaper way. Organic carbon molecules make the structural backbone of pyruvate and acetyl CoA, and also play an important role in the formation of VFA. Moss et al. (2000) extensively described the conditions of acetate, propionate and butyrate production during anaerobic fermentation (Figure 3). Metabolic hydrogen in the form of reduced protons $(\mathrm{H})$ can also be used during the synthesis of volatile fatty acids or incorporated into microbial organic matter. When $\mathrm{H}_{2}$ is not correctly used by methanogens, NADH can be re-oxidized by dehydrogenases of the fermenting bacteria to form ethanol or lactate. This situation occurs when large amounts of rapidly fermentable carbohydrates are supplied to the animals indicating the dysfunction of the ruminal ecosystem. Muetzel et al. (2009) found that the total VFA concentrations were substantially lower than that typically found in the rumen, but similar to other in vitro reports. Relatively low concentration of substrate during in vitro fermentations might be the cause of lower VFA. 


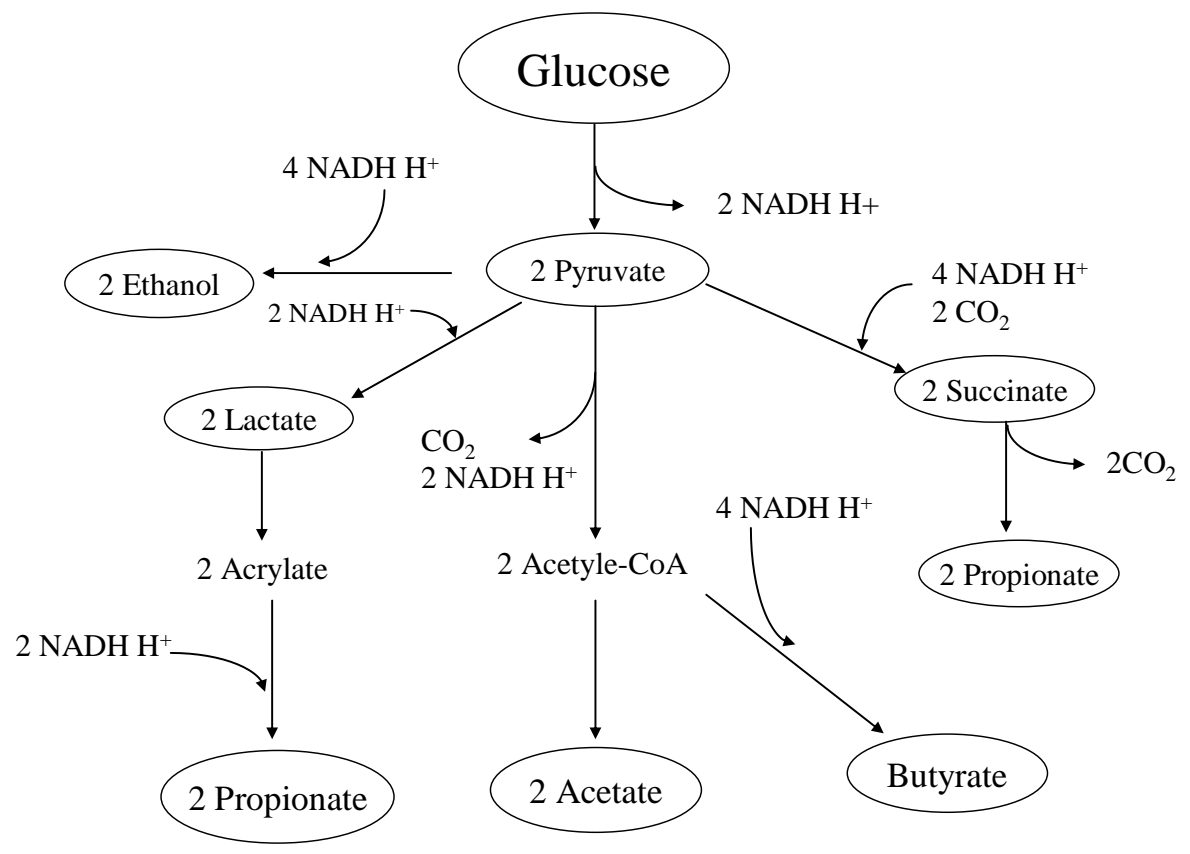

Figure 3. Mechanism of VFA production from simple sugar (Moss et al., 2000).

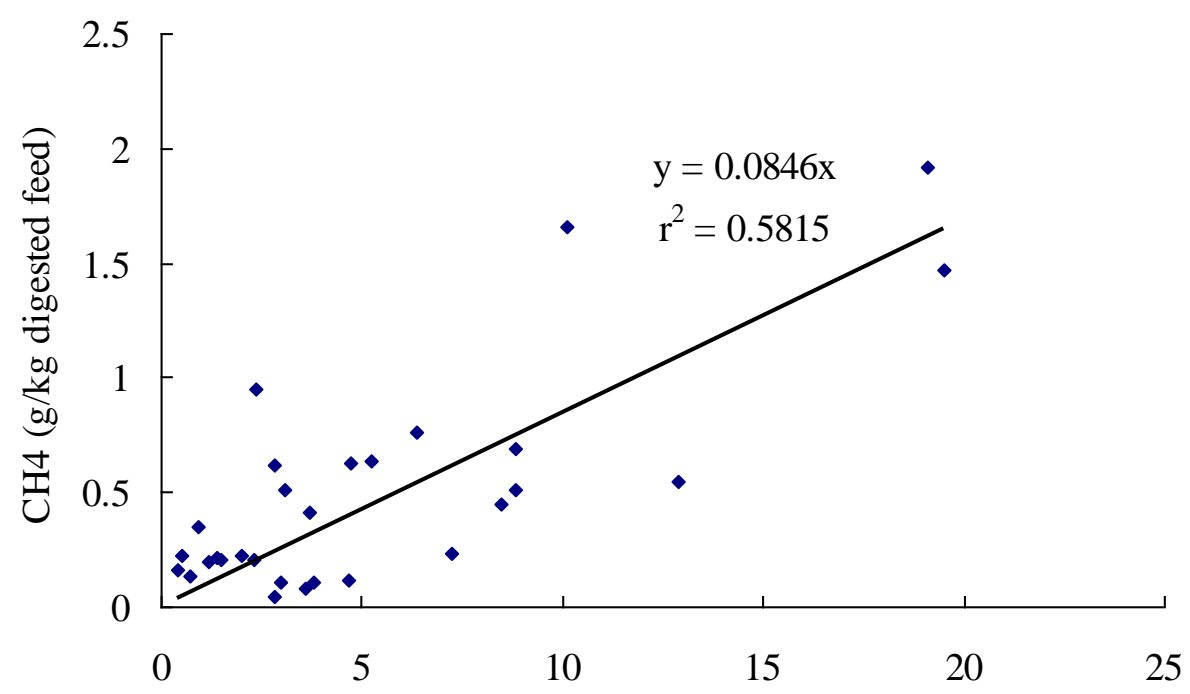

Acetic acid production (mole/kg digested feed)

Figure 4. Correlation between acetic acid and $\mathrm{CH}_{4}$ production.

Relationship between VFA and methane $\left(\mathrm{CH}_{4}\right)$ production of feeds during in vitro fermentation was also estimated in this experiment. Results found that the produced $\mathrm{CH}_{4}$ was proportional to the acetate $(\mathrm{y}=$ $\left.0.0846 x, r^{2}=0.58\right)$, and total VFA $\left(y=0.0508 x, r^{2}=0.58\right)$ production (Figures 4 and 5, respectively) during $48 \mathrm{~h}$ of in vitro fermentation. It might be assumed from the above regression lines that the amount of $\mathrm{CH}_{4}$ could be estimated from the produced acetate and total VFA during in vitro fermentation, without direct measurement. So, acetate and total VFA would also be used as indirect index for $\mathrm{CH}_{4}$ estimation. Methane production is one of the important criteria for anaerobic fermentation of feeds and it has a relation with VFA production. Overall positive correlation between total VFA and $\mathrm{CH}_{4}$ gas production supports the statement of Kamalak et al. (2002). They stated that the $\mathrm{CH}_{4}$ production was proportional to total VFA production. Amylolytic bacteria like Prevotella 


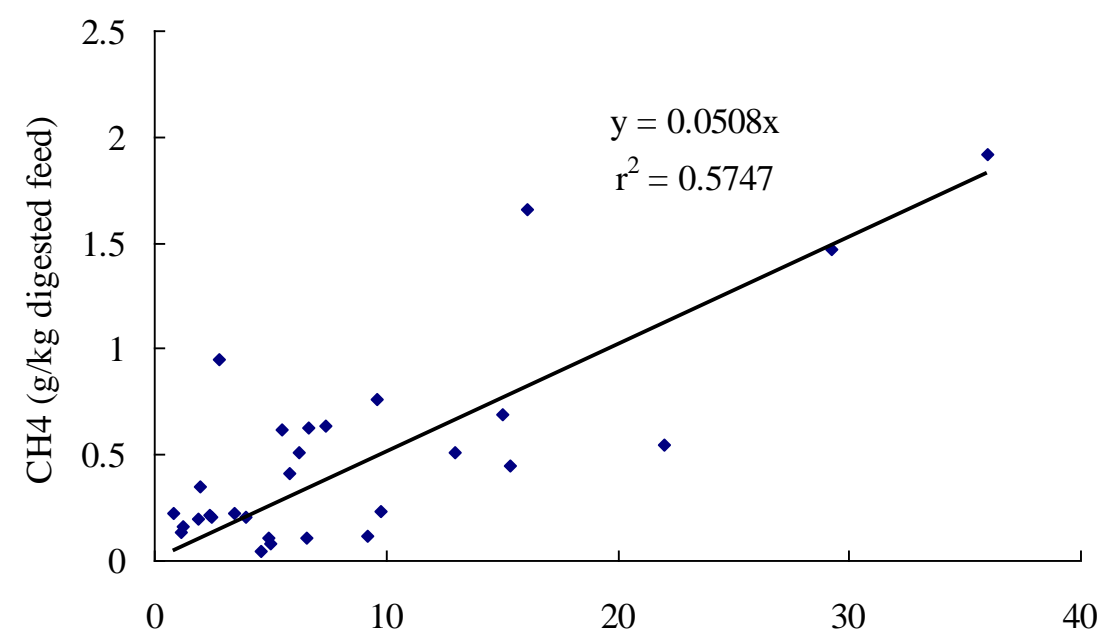

Total VFA production (mole/kg digested feed)

Figure 5. Correlation between total VFA and $\mathrm{CH}_{4}$ production.

ruminicola and Butyrivibrio fibrisolvens synthesize acetate and butyrate that helps to produce $\mathrm{H}_{2}$ and $\mathrm{CO}_{2}$. These $\mathrm{H}_{2}$ and $\mathrm{CO}_{2}$ are the raw materials of $\mathrm{CH}_{4}$ formation (Rossi et al., 2001) and this process is influenced by methanogens. Getachew et al. (2005) stated that $\mathrm{CH}_{4}$ and $\mathrm{CO}_{2}$ production from in vitro digestion technique is the result of fermentation of short chain fatty acids and it is highly proportional to acetate and butyrate production. Types of VFA affect the amount of $\mathrm{CH}_{4}$ production; propionate decreases the overall gas production, but acetate linearly increased the gas production. Methane is produced mainly when the feed is fermented to acetate and butyrate, in contrast, relatively lower $\mathrm{CH}_{4}$ gas production is occurred with propionate production (de Groot et al., 1998).

Gas is produced mainly when feed materials are fermented to acetate and butyrate. Fermentation of feed materials to propionate yields gas only from buffering of the acid and, therefore, relatively lower gas production is associated with propionate production (Van Soest, 1994). The gas which is released with the generation of propionate is only the indirect gas produced from buffering. The molar proportions of different VFA (acetate, propionate and butyrate) produced is dependent on the type of feed materials (Blummel and Orskov, 1993). If fermentation of feed materials leads to a higher proportion of acetate, there will be a concomitant increase in gas production as compared to a feed with a higher proportion of propionate. In other words, a shift in the proportion of VFA will be reflected by changes in gas production (Getachew et al., 1998). Methane production occurred when substrate is fermented to acetate and butyrate. So, the molar ratio of acetate to propionate was used to evaluate substrate related differences. Many workers reported more propionate and thus a lower acetate to propionate ratio in the ruminal fluid of cows fed a high grain diet. If fermentation of feeds leads to a higher proportion of acetate, there will be a concomitant increase in gas production when compared with a feed with a higher proportion of propionate.

\section{$\mathrm{pH}$ changing pattern of feedstuffs during in vitro fermentation}

A decreasing $\mathrm{pH}$ changing pattern was observed in all feeds during $48 \mathrm{~h}$ of in vitro fermentation. The initial and final $\mathrm{pH}$ ranged from 6.57 to 7.00 and 5.49 to 6.53 , respectively. The $\mathrm{pH}$ of the liquid media decreased gradually with the increase of time within $48 \mathrm{~h}$. Readily available carbohydrates in the energy and protein rich feeds and cellulose and hemi-cellulose of the forages were converted into simple sugar by the enzymatic action of microorganisms. Furthermore, the rumen microbes produced the acetic acid, propionic acid and butyric acid (VFA) by utilizing the sugars that might be the reason for decreasing $\mathrm{pH}$ during in vitro fermentation. Produced VFAs are continuously transported to the liver after absorbed into the blood stream through epithelium. Continuous removal of VFA from the rumen is important not only for distribution, but also to prevent excessive acidity of rumen fluid. Van Kessel and Russel (1996) stated that type of feed has an influence on ruminal $\mathrm{pH}$ and found a constant $\mathrm{pH}$ (6.7 to 6.9) in forage fed fistulated cow, but a comparative lower $\mathrm{pH}$ in concentrate fed cows. The cellulolytic bacteria Fibrobacter succinogenes is the major propionate producers through the succinate pathway in forage diets, while lactate is the main intermediate in the conversion of starch to propionate. Unlike cellulolytic bacteria and methanogens, lactic acid 
bacteria are known to be tolerant to low $\mathrm{pH}$ and making them able to use $\mathrm{H}_{2}$. Thus, the lactic acid bacteria is competitive with methanogens even in unfavorable $\mathrm{pH}$ conditions (Moss et al., 2000).

\section{Conclusion}

It was found from the experiment that TOC and VFA have a positive correlation during in vitro fermentation. Correlation co-efficient between TOC and VFA would be an important parameter to identify VFA from TOC value. So, it might be assumed that TOC would be an important tool to measure the amount of VFA. Determination of VFA from livestock feeds is very complex and expensive. Thus, it would be a cost effective procedure of indirect estimation of VFA from TOCs produced.

\section{ACKNOWLEDGEMENTS}

We are grateful to Rural Development Administration, Korea for funding the research. Also, this work was supported in part by a grant from the Institute of Animal Resources at Kangwon National University, South Korea.

\section{REFERENCES}

AOAC (2005). Official Methods of Analysis, 16th Ed. Association of Official Analytical Chemist, Washington D. C., USA.

Bannink A, Kogut J, Dijkstra J, France J, Kebreab E, Van Vuuren AM, Tamminga $S$ (2006). Estimation of the stoichiometry of volatile fatty acid production in the rumen of lactating cows. J. Theor. Biol. 238:3651.

Blummel M, Orskov ER (1993). Comparison of gas production and nylon bag degradability of roughages in predicting feed intake in cattle. Anim. Feed Sci. Technol. 40:109-119.

de Groot JCJ, Williams BA, Oostdam AJ, Boer H, Tamminga S (1998). The use of cumulative gas and volatile fatty acid production to predict in vitro fermentation kinetics of Italian ryegrass leaf cell walls and contents at various time intervals. Br. J. Nutr. 79:1-7.

Dijkstra J, Kebreab E, Bannink A, France J, Lopez S (2005). Application of the gas production technique to feed evaluation systems for ruminants. Anim. Feed Sci. Technol. 123-124:561-578.

Dougherty RW (1984). Physiology of the Ruminant's Digestive Tract. In: M. Swenson (Ed.) Duke's Physiology of Domestic Animals. pp 351 358. Cornell Univ. Press, New York. USA.
Getachew G, Blummel M, Makkar HPS, Becker K (1998). In vitro gas measuring techniques for assessment of nutritional quality of feeds: a review. Anim. Feed Sci. Technol. 72:261-281.

Getachew G, Robinson PH, DePeters EJ, Taylor SJ, Gisi DD, Higginbotham GE, Riordan TJ (2005). Methane production from commercial dairy rations estimated using an in vitro gas technique. Anim. Feed Sci. Technol. 123-124:391-402.

Kamalak A, Gurbuz Y, Finlayson HJ (2002). Comparison of in vitro dry matter degradation of four maize silages using the Menke gas production method. Turk. J. Vet. Anim. Sci. 26:1003-1008.

Keir B, Lai NV, Preston TR, Orskov ER (1997). Nutritive value of leaves from tropical trees and shrubs. 1. In vitro gas production and in sacco rumen degradability. Livest. Res. Rural Dev. 9:24-30.

Menke KH, Steingass $\mathrm{H}$ (1988). Estimation of the energetic feed value obtained from chemical analysis and in vitro gas production using rumen fluid. Anim. Res. Dev. 28:7-55.

Moss AR, Jouany JP, Newbold J (2000). Methane production by ruminants: its contribution to global warming. Ann. Zootech. 49:231253.

Muetzel S, Lawrence P, Hoffman EM, Becker K (2009). Evaluation of a stratified continuous rumen incubation system. Anim. Feed Sci. Technol. 151:32-43.

Orskov ER, Ryle M (1990). Energy Nutrition in Ruminants. Elsevier, London, UK p. 149.

Rossi F, Vecchia P, Masoero F (2001). Estimate of methane production from rumen fermentation. Nutrient Cycling Agroecosyst. 60:89-92.

Tilley JMA, Terry RA (1963). A two-stage technique for the digestion of forage crops. J. Br. Grassl. Soc. 18:104-111.

Van Kessel JAS, Russell JB (1996). The effect of $\mathrm{pH}$ on ruminal methanogenesis. FEMS Microbiol. Ecol. 20:205-210.

Van Soest PJ (1994). Nutritional Ecology of Ruminants. 2nd edn. Cornell University Press, New York, USA p. 476

Weimer PJ, Stevenson DM, Mertens DR, Hall MB (2011). Fiber digestion, VFA production, and microbial population changes during in vitro ruminal fermentations of mixed rations by monensin-adapted and unadapted microbes. Anim. Feed Sci. Technol. 169:68-78.

Widiawati Y, Thalib A (2007). Comparison fermentation kinetics (in vitro) of grass and shrub legume leaves: The pattern of VFA concentration, estimated $\mathrm{CH}_{4}$ and microbial biomass production. JITV, J. Anim. Vet. Sci. 12:96-104. 